\title{
MAPPING COUNTER-TRAFFICKING IN POTENTIAL MIGRANT CRISIS IN BOSNIA AND HERZEGOVINA
}

Elmedin MURATBEGOVIĆ, PhD

Faculty of Criminal Justice Sciences, Criminology and Security Studies, University of Sarajevo,

E-mail: emuratbegovic@fkn.unsa.ba

Marija LUČIĆ-ĆATIĆ, PhD

Faculty of Criminal Justice Sciences, Criminology and Security Studies, University of Sarajevo,

E-mail: mlucic@fkn.unsa.ba

\section{Abstract:}

Bosnia and Herzegovina, as a post-war country in transition with close proximity to the European Union, complex political structure, underdeveloped economy, high number of refugees and internally displaced persons, young migration management structure, porous borders and limited resources, has been struggling with the phenomenon of human trafficking for almost two decades now. The migratory movements through Bosnia and Herzegovina occurs against a background of ongoing challenges related to countering trafficking in persons (TIP). Significant percentage of migrants and refugees transiting may be vulnerable to potential exploitation and abuse along the route. That being said, to date, only few victims have been identified among migrants and refugees in countries along the Western Balkan route. This paper is based on desk review of BH TIP capacities in available key documents and current researches and qualitative survey conducted through interviews using qualitative questionnaire developed by authors of this paper. An online search was performed for all available documents related to trafficking in people. Key informants were selected, according to the areas of their expertise. Those were experts from following agencies/organizations: National coordinator's office for the fight against trafficking in human beings, Prosecutors' office of Bosnia and Herzegovina, Service for Foreigners, NGO IFS EMMAUS, and Immigration Centre. Key informants were asked to talk about their respective roles in counter TIP activities, about their perception of the established counter human trafficking system, indicators of human trafficking and link with mixed migration flows, to list examples of good practices and barriers for better identification of victims and potential victims of trafficking.

Key Words: Bosnia and Herzegovina, migrants, refugees, crisis, trafficking, capacities 


\section{Introduction}

The research resulted in the paper that will be disseminated to stakeholders and raise awareness regarding recent changes in trafficking in person (TIP) trends since the closing of the border along the Western Balkan migration route and be able to develop their own interventions according to the new highlighted trends. Bosnia and Herzegovina, as a post-war country in transition with close proximity to the European Union, complex political structure, underdeveloped economy, high number of refugees and internally displaced persons, young migration management structure, porous borders and limited resources, has been struggling with the phenomenon of human trafficking for almost two decades now. The migratory movements through Bosnia and Herzegovina occurs against a background of ongoing challenges related to countering trafficking in persons (TIP). Significant percentage of migrants and refugees transiting may be vulnerable to potential exploitation and abuse along the route.

This paper is based on desk review of BHTIP capacities in available key documents and current researches and qualitative survey conducted through interviews using qualitative questionnaire developed by authors of this paper. An online search was performed for all available documents related to trafficking in people. Key informants were selected, according to the areas of their expertise. Those were experts from following agencies/organizations: National coordinator's office for the fight against trafficking in human beings, Prosecutors' office of Bosnia and Herzegovina, Service for Foreigners, NGO IFS EMMAUS, and Migrant from Immigration Centre. Key informants were asked to talk about their respective roles in counter TIP activities, about their perception of the established counter human trafficking system, indicators of human trafficking and link with mixed migration flows, to list examples of good practices and barriers for better identification of victims and potential victims of trafficking.

\section{Counter Trafficking in Potential Migrant Crisis in the Bosnia and Herzegovina}

\section{Counter TIP system}

Bosnia and Herzegovina has invested significant efforts since 2001 to establish a comprehensive anti-trafficking mechanism in the country, the so-called National Referral Mechanism (NRM), including strategic planning of anti-trafficking actions, legislative amendments and harmonisation with international standards, training and capacity building of government institutions and non-state actors, and creation of efficient coordination mechanisms. (IOM Trafficking in Persons Report, 2017)

The institutional anti-trafficking framework includes three main coordination mechanisms: State Coordinator for Combatting Trafficking in Human Beings and Illegal Migration in Bosnia and Herzegovina (CTHB). Responsible for leading and coordinating the country anti-trafficking efforts at the policy level, and chairing the inter-institutional team for monitoring the implementation of the Strategy and Action Plan. Furthermore, the SC Office in practice coordinates the work of the Regional Monitoring Teams (RMTs) and often convenes their meetings. At the operational level, 
the SC Office occasionally facilitates ad hoc referral and cooperation among RMTs members, for example to facilitate victim's access to services in concrete THB cases (Mujanović, et.al., 2010)

Strike Force for Fight against Trafficking in Human Beings and Organised Illegal Immigration: Mechanism for coordination of law enforcement agencies between State, Entity and Brčko District in fighting THB. It is established under the direct management of the B\&H Chief Prosecutor with a specific and considerable budgetary allocation. It is responsible for ensuring operational cooperation and exchange of intelligence in relation to investigation of THB cases throughout the country. On invitation, an NGO representative participates in the work of the Strike Force, to discuss and arrange operational aspects of victim assistance when deemed necessary.

Regional Monitoring Teams (RMTs): Multidisciplinary teams involving public officials from multiple institutions: Ministry of Security (MoS), Ministry of Human Rights and Refugees (MHRR), Ministry of Justice (MoJ), Ministry of Civil Affairs (MCA), Agency for Gender Equality, BiH Prosecutor's Office, State Investigation and Protection Agency (SIPA), Border Police, Service for Foreigner's Affairs (SFA), police, prosecutor's offices, social welfare centres, health care services, labour inspectorates, officials from the Ministries of Education, local NGOs and other public officials at Entity, cantonal and Brčko District level (Rizvo, et.al., 2010)

There are four operational RMTs in BiH: Sarajevo, Mostar, Banja Luka and Tuzla. The RMTs are established on the basis of Article 22 of the Rules on the Protection of Victims and Victim Witnesses of Trafficking in Human Beings BIH Nationals. Their main mandate is to establish local referral mechanisms for victim identification and assistance. According to the Guidelines for RMTs for the Fight against Human Trafficking, they are also involved in prevention of THB, analysis of the phenomenon and capacity building. The RMTs are very large coordination mechanisms - involving around 60-70 participants in some locations (e.g. Sarajevo) and thus they provide mainly a forum for exchange of information and for establishment of contacts with counterparts in other public institutions and $\mathrm{NGOs}$.

The infrastructure for the establishment of an NRM is complemented by two bylaws on protection of domestic and foreign victims. Here it is worth noting that none of the two documents mentions labour inspectorates, labour migration authorities and trade unions, although trafficking for labour exploitation has been on the rise in recent years, and these additional actors would need to be operationally involved in the NRM. (Mujanović, et.al. 2010). With regard to establishing clear roles, mandates and tasks of each actor in the NRM process of identification and assistance, over recent years, numerous guidelines targeting specific professional groups have been developed. A number of NGO projects were also implemented in partnership with state institutions to build the capacity of various actors in the NRM. However, in practice it would seem that these efforts have not reached a critical mass, and hence the existing guidelines are not yet widely known, understood, shared and accepted by each professional group/actor involved in the process of victim identification, referral and assistance (Rizvo, et.al. 2010). 


\section{Gaps in identification of potential VoIs within the mixed migration flows}

Trafficking has further developed in country, by altering its trends and patterns with respect to organisation of traffickers, forms of recruitment, purpose and type of exploitation, types of control imposed upon victim, routes of traffickers and victims as well as profile of persons involved in process. Such situation imposes new, complex and growing challenges to the authorities and society. It reiterates a requirement to raise awareness and knowledge on trafficking by both general public and professionals as well as to develop evidence based policy aimed at suppressing trafficking. (Muratbegović, et.al. 2010). The gaps in resources for the identification and referral of potential VoTs within the mixed migration flows in your country are:

- Lack of energetic, decisive research of cases involving trafficking for purpose of sexual and labour exploitation accompanied by less aggressive process of indicting and prosecuting traffickers representing the first and likely paramount deficiency within a counter trafficking system. (IOM - Trafficking in Persons Report, 2017)

- This attitude has corresponded with general perception of public that criminal judiciary response to criminal operations and penal policy associated with trafficking has been very mild. Major problems associated with efficient trafficking prosecution stem from drastic and various interpretations of criminal legal provisions on trafficking, which result with different law enforcement practices by prosecutors and police. (Rizvo, et.al., 2006)

- As a result, there has been a confusing court practice present to this end. At times, investigations are launched as cases of trafficking, but further continue as a case of instigating to prostitution or parent's neglecting of a child (Muratbegović, et.al., 2010), (IOM - Trafficking in Persons Report, 2017)

- Prosecutors do not apply same standards, and do not have same skills and experience in cases involving trafficking, which may cause certain level of victim's discrimination due to inappropriate level of protection and support. Police officers lack experience and training to recognise potential VoTs within the mixed migration flows, which occurs in many forms, including through labour exploitation primarily. Also, trafficking within the mixed migration flows cases have not been a familiar form of trafficking for judiciary (Strategy to counter trafficking in human beings in Bosnia and Herzegovina 2013-2015., 2013)

A detailed analysis is required to determine gaps in criminal prosecution actions in order to overcome those deficiencies and ensure efficient investigations and prosecution of those crimes. That action would lead to imposing appropriate sanctions and deter potential traffickers from undertaking criminal operations. Special attention is to be paid to new forms of trafficking for purpose of labour exploitation and child trafficking, including the use of special surveillance means (Strategy in the area of migrations and asylum and action plan for the period 2016-2020., 2016).

The following deficiency is an absence of efficient mechanism to suppress corruption associated with trafficking. Trafficking and corruption have been closely and frequently associated activities. The process of overcoming this deficiency is dependent on actual method of treatment. 
At first, it is necessary to acknowledge corruption and its impact to trafficking. Therefore it has been important to explore the role of corruption in trafficking and its impact on trafficking augmentation.

Secondly, it is necessary to investigate and prosecute acts of corruption decisively, including identification of the most present forms of corruption associated with trafficking. Such approach would lead to stop the practice of separate criminal prosecutions of trafficking and corruption cases related to individuals who allowed or tolerated trafficking. There are some typical forms of corruption associated with trafficking such as: use of forged travel documents to transport (transfer) victims of trafficking, issuance of visa or other travel documents (laissez passer) without meeting required conditions, etc. Aforesaid could be accomplished by improved legal framework governing these subjects and by harmonising practices and know-how of the institutions in charge of combatting trafficking in order to build their capacity to recognise such criminal activities (Strategy to counter trafficking in human beings in Bosnia and Herzegovina 2013-2015., 2013).

The third relevant deficiency is pro-active approach to field work aimed at identifying victims, in particular those forced to beg at public places and subjected to other forms of exploitation (primarily targeting children). Bosnia and Herzegovina must ensure that its law enforcement officers, labour inspectors, social workers and other officers apply pro-active approach and undertake intensified actions aimed at detecting and saving potential victims of trafficking, particularly of the most vulnerable ones - children subjected to exploitation by other adults. At the same time, further actions need to be undertaken in order to provide appropriate assistance and protection to victims. In addition, it is required to make efforts to facilitate victims' reintegration to society, including having traffickers compensate damage to victims. Therefore any future training should be designed to improve knowledge and skills on providing appropriate assistance and protection to victims of trafficking (Rizvo et al, 2015).

The fourth deficiency has been associated with a low level of awareness on trafficking, in particular concerning new forms of labour exploitation and children exploitation at public places. Thus, it is required to conduct comprehensive public campaigns targeting general public and also specifically tailored campaigns targeting vulnerable groups. Those actions, serving as deterrents must coincide with implementation of other widespread actions aimed at improving general living conditions and standards of vulnerable groups including women, children, minorities, refugees and internally displaced persons (Rizvo et al, 2006).

The fifth deficiency is associated with absence of relevant research on trafficking in order to determine the scope and trends of trafficking, as well as factors favouring and facilitating trafficking in BiH. Additionally, the relevant research should contain recommendations for future counter - trafficking policy and actions taken by government and civil society. In this regard, this subject research tends to make available certain knowledge and propose some solutions which will facilitate counter trafficking efforts (IOM - Trafficking in Persons Report, 2017).

All individuals travelling in an irregular fashion are exposed to hardship and danger. However, some categories of individuals are of special concern as they are particularly vulnerable. This chapter speaks about some of different categories of vulnerable individuals in mixed migration 


\section{Securitity}

flows. Many of these categories are complex to identify and require specialised determination processes.

The key role of frontline officials is to provide immediate protection and assistance to migrants they think are in vulnerable situations, and refer them to appropriate authorities for further screening and support. (Strategy in the area of migrations and asylum and action plan for the period 2016-2020., 2016). The categories covered below include a wide range of vulnerable individuals within mixed migration flows. First line officials need to be aware they also may encounter vulnerable individuals who do not fall under those categories but who need assistance, including elderly migrants, migrants with disabilities or serious health conditions, pregnant women, migrants in need of family unification, and others (IOM \& UNHCR, 2017).

People who migrate regularly, with valid travel documents, may also fall victim to traffickers, but the irregular situation of many migrants in irregular movements makes them particularly vulnerable. Unaccompanied children, stranded migrants, refugees and asylum seekers and stateless persons among mixed migration flows are particularly susceptible.

Many individuals who travel as part of mixed migration flows, may be unaware that they may become victims of trafficking, assuming that they are merely smuggled to another country. Smuggled migrants voluntarily enter into arrangements with migrant smugglers but may subsequently become victims of crimes, including kidnapping, extortion, rape, assault and trafficking in persons (Strategy in the area of migrations and asylum and action plan for the period 2016-2020., 2016)

Some smugglers may put migrants into exploitative situations on the basis of paying off their smuggling debts. Because of all of this, we have created a special set of feedback for the National TIP Coordinator in order to find out about the new forms of TIP within the migration crisis. We set the next question, What they think about cases in their Bosnia and Herzegovina (see Table 1)

- Migrants reported to have paid smugglers to be hidden from the public spaces, but they were then forced to remain in a closed space against their will.

- Migrants having worked or provided services for someone during their journey without receiving the expected or any remuneration in return.

- Migrants have been forced to work or perform activities against their will

- Migrants reported having been approached with offers of an arranged marriage (for the respondent or for a close family member)

- Migrants REPORTED that they experienced physical violence

- Migrants were offered money in exchange for blood, organs or body parts

- Migrants FORCED to give blood, organs or body part

- Migrants threatened with sexual violence? 


\section{Security}

Table 1: Forms of exploitations in the mixed migration flows in B\&H (IOM - Flow Monitoring Surveys, 2017)

\begin{tabular}{|l|c|}
\hline ... were held against their will & No \\
\hline ........no of cases within FMS2017 Survey & - \\
\hline ... have worked without getting the expected payment & No \\
\hline ........no of cases within FMS2017 Survey & - \\
\hline ... were forced to work & No \\
\hline ........no of cases within FMS2017 Survey & - \\
\hline ... offers of an arranged marriage & No \\
\hline ........no of cases within FMS2017 Survey & - \\
\hline ... experienced physical violence & No \\
\hline ........no of cases within FMS2017 Survey & - \\
\hline ... cash in exchange for blood, organs or body parts & No \\
\hline ........no of cases within FMS2017 Survey & - \\
\hline ... F0.RCED to give blood, organs or body part & No \\
\hline ........no of cases within FMS2017 Survey & - \\
\hline ... threatened with sexual violence & No \\
\hline ........no of cases within FMS2017 Survey & - \\
\hline
\end{tabular}

Lets to see, what National TIP Coordinator think about special mobile phone app, developed to provide smartphone accessible and useful information for migrant? Is it useful?

Table 2: Technical help for Migrants in B\&H

\begin{tabular}{|l|l|}
\hline$\ldots$ there is an SOS phone for migrants in your country & No \\
\hline ... there is other technical help for migrants & No \\
\hline
\end{tabular}

In the forthcoming phase we talked to 30 migrants (Camps in: $\mathrm{BiH}$ ) about the same topic as with National TIP Coordinators. Their experience and bad experiences in migration were interesting to us.

What Migrants think about special mobile phone app, developed to provide smartphone accessible and useful information for migrant? Is it useful for them? The most frequent answers were: 
- "Good idea. Is possible to set some kind of translator with legal terms, to better explain situation, something as Google translator. Advices, how to apply for asylum etc

- "That is very necessary. It is very dangerous to be bad or non-informed, or confused..-addresses of asylum centres (how to apply for asylum and security advices)"

- "Good idea.. Advices on help centres, legislation of various countries on various languages addresses of help centres, advices on how and what to do etc"

- To be able to contact my parents and close family in the country of origin, from every country 1 am traveling through.

- Information regarding the safety of the road and the route that I am traveling through. Also information about the possibilities for asylum and employment in the countries I am traveling through.

- Information regarding the safety of the road and the route that I am traveling through. Also information about the possibilities for asylum and employment in the countries I am traveling through. This information would be useful for me because I have BA, and I would like to go to a country where I can use my knowledge.

- Information regarding locations of all migrants camps in the countries, borders of countries where I am traveling through, safe road for traveling, and maybe information about weather forecast

- It would be useful to have a phone number for hospitals and other institutions.

- Which is the nearest camp? Is this camp safe and could s/he be accepted/accommodated in it? What NGOs are present in the camp? Numbers of $\mathrm{CO}$ s such as police, hospital...?

\section{Forms of exploitation - migrants experience}

Migrants reported to have paid smugglers to be hidden from the public spaces, but they were then forced to remain in a closed space against their will in many cases. The most frequent answers were:

- ....just during travel, paid to smugglers 200EUR"

- "... just during travel, paid to smugglers 1000 EUR"

- "...just during travel, paid to smugglers 500 EUR"

- "...paid 4500 EUR to smugglers, have been locked for 3 days at the forest house"

- "... have been closed for 2 days in the forest house in Croatia where I was settled by the smuggler, paid 4500EUR"

- ".... 3 days in the house in the middle of the forest, paid 4200EUR"

- "... have been closed for 4 days in the truck, paid 1500 EUR"

- "... Paid 5500 EUR in total. I have been hidden in truck for 4 days, smuggled on route Greece heading to Croatia"

- "...Paid 6000 EUR in total. Have been hidden in truckfor 3 days in Turkey and for 2 days on route Greece heading to Croatia" 
- "... I had to pay to a smuggler to hide me from public spaces, paid 1000 euros to get from Thessaloniki-Greece to Belgrade-Serbia"

- .... Yes, it happened in Turkey. I was imprisoned in a n abandoned house, where I was hold for eight days. I escaped from the house while the smuggler was out"

Migrants REPORTED that they experienced different type of physical violence.

- "I have been beaten by the Romanian police, uniformed. In Serbia I have been beaten by ordinary citizens of Serbia"

- "I have been beaten by Croatian police. Hurt legs and hands. Not head nor torso, just hands and legs"

- "I have been beaten by Serbian smugglers, during the transport, when asked for sandwich but had no additional cash..."

- "I have been beaten by uniformed Croatian police. They took my mobile and never got it back"

- "I have been beaten in the truck, during the transport by smugglers, on route Greece-Croatia, after l asked for some food"

- "Algerian migrant attacked my by knife in Serbia. I have been wounded (visible scars on lower part of leg)"

- "I have been beaten several times while travelling across Iran. He thinks that he was beaten 5 or more times by Iranian smugglers and civilians. Reason was that he had no more cash to give them"

In a many cases, while the migrant was kept in the smuggler's house in the village at the Macedonian - Serbian border, he experienced physical violence several times. They attacked them in order to pay just to continue to his final destination. The migrant was even left with no clothes and threatened that the smugglers would take his organs if he did not pay.

Migrants were beaten in Greece by Greek police officers. Since they did not have any documents with them, the police wanted to take them to police station. They refused, and afterwards they were beaten. Finally police took them to police station, where they were kept for one hour and then released.

\section{Unaccompanied and separated children in migration}

The UN Committee on the Rights of the Child has identified a number of protection gaps in the treatment of such children, including that unaccompanied and separated children face greater risks of, inter alia, sexual exploitation and abuse, military recruitment, child labour (including for foster families) and detention. In many countries, unaccompanied and separated children are routinely denied entry to or detained by border or immigration officials. In other cases, they are admitted but are denied access to asylum procedures, or their asylum claims are not handled in an age and gender-sensitive manner. Some countries impede separated children who are recognised 


\section{Security}

as refugees from applying for family reunification. Many such children are granted only temporary status, which ends when they turn 18, and there are few effective return programmes (Termiz, et.al. 2010).

The vulnerable situation of migrant unaccompanied and separated minors worldwide, and the threats they face need to be addressed, particularly with the significant increase in their number in the current 'refugee crises. The 2016 State of the Union speech called for a strong and immediate protection of unaccompanied and separated minors, in line with the EU's historical values (Feltz, 2015).

In this paper we have created a special set of feedback for the BH National TIP Coordinators in order to find out about the new problems of unaccompanied and separated children in migration within the migration crisis (see Table 3).

Table 3: Unaccompanied and separated children in migration (UASC) - effective system in B\&H

\begin{tabular}{|l|c|}
\hline $\begin{array}{l}\text { Does Your State take measures to have an effective system of guardianship } \\
\text { which takes into account the specific needs and circumstances of unaccom- } \\
\text { panied and separated children in migration in order to protect and promote } \\
\text { their rights and secure their best interests }\end{array}$ & Yes \\
\hline $\begin{array}{l}\text { Are separated children, present in their jurisdiction effectively provided } \\
\text { with guardianship (alongside legal assistance) and representation, prompt- } \\
\text { ly after identification as an unaccompanied child }\end{array}$ & Yes \\
\hline $\begin{array}{l}\text { Representation and guardianship - Is there a requirement to ensure that } \\
\text { the child is represented throughout the entire process }\end{array}$ & Yes \\
\hline Child is represented by Social Welfare Service? & Yes $^{1}$ \\
\hline Are there any exceptions regarding children based on age & No \\
\hline Is s/he always informed in a language s/he can understand? & No \\
\hline
\end{tabular}

An age assessment is a procedure organised by a public body to determine the chronological age of an individual lacking legal documents. Being considered an "undocumented migrant" by the administration and not an "unaccompanied child" may have serious consequences. If the age assessment concludes that the individual is 18 years of age or older, s/he will not benefit from the protective regime afforded to child asylum-seekers which includes lodging, access to healthcare and education and legal provisions limiting the recourse to detention. Incorrect age assessments often result in children being wrongfully detained or made homeless. Negotiating who should benefit from the rights afforded by childhood on the basis of arbitrary measurements is inacceptable (Feltz, 2015).

To ensure the highest degree of protection of the rights of the child during age assessment, it is necessary to approach every step from the perspective of the best interests of the child, 
including his or her own particular circumstances. They must be a primary concern, even over the State's political interests.

As we can see, in the region of WB there are no statutory procedures, protocols, guidance or recommendations issued on age assessment procedures by different authorities. In addition, the concern relates to the fact that domestic courts have not examined the application of age assessment procedures in individual cases (see Table 4).

Table 4: UASC - Age Assessment Procedures in B\&H: Statutory procedure

\begin{tabular}{|l|c|}
\hline $\begin{array}{l}\text { Is there any statutory procedure, protocol, guidance or recommenda- } \\
\text { tions issued on age assessment procedures by different authorities? }\end{array}$ & No \\
\hline $\begin{array}{l}\text { Have domestic courts examined the application of age assessment } \\
\text { procedures in individual cases? }\end{array}$ & No \\
\hline
\end{tabular}

Every country is free to choose the method used to scrutinise the age of an individual. The most common are wrist/carpal $x$-rays, followed by dental examinations and dental $x$-rays. To a lesser degree, collar bone and hip $x$-rays as well as physical development assessments are also used.

When it comes to the methods used to determine the age of unaccompanied children in migration in WB countries, we can see the prevailing "social oriented" methods: Documents submitted or obtained during the process, Estimation based on physical appearance, Age assessment interview, Social services assessment and Psychological evaluation. On the other hand, other methods are completely unknown to the countries 0 . (see Table 5).

Table 5: Unaccompanied and separated children in migration - age assessment procedures in $B \& H$

\begin{tabular}{|l|l|}
\hline $\begin{array}{l}\text { Documents submitted or obtained during the } \\
\text { process }\end{array}$ & No \\
\hline Estimation based on physical appearance & $\mathrm{Yes}^{2}$ \\
\hline Age assessment interview & $\mathrm{Yes}^{3}$ \\
\hline Social services assessment & $\mathrm{Yes}^{4}$ \\
\hline Psychological evaluation & $\mathrm{Yes}^{5}$ \\
\hline Dental observation & No \\
\hline Physical development observation & No \\
\hline Carpal (hand/wrist) x-ray & No \\
\hline Collar bone x-ray & No \\
\hline Dental x-ray (wisdom/front teeth) & No \\
\hline Sexual maturity observation & No \\
\hline
\end{tabular}




\section{Security}

The European Union has competence to deal with 'legal migration' (e.g. people coming to Europe on invitation of a specific employer, family reunification, etc.) and hence to lay down conditions of entry and residence of third-country nationals. The EU is also competent to prevent and reduce 'irregular migration' according to article 78 and 79 of the Treaty on the Functioning of the EU (TFEU). This means that the EU is competent to legislate on common standards concerning age assessment. Article 25 of the Directive on common procedures for granting or withdrawing international protection ("Asylum Procedures Directives") authorises the use of medical examination in order to determine the age of an unaccompanied minor in European Law. It does not specifically deal with the different existing methods, but lays down rights and safeguards for the child: to be provided with legal and procedural information free of charge, to have a representative appointed, personal interview(s) conducted by a qualified professional, a presumption of minority, the use the least invasive method, informed consent, the fact that no decision of non-minority can be based solely on a refusal to undergo medical examination, and finally the protection of the best interests of the child. Consequently, the Commission will be very interested to receive NGO observations that expose systematic violations of these safeguards.

An incorrect age assessment can have grave consequences by denying vulnerable UASC the services that they are entitled to and putting them at risk. For example, young girl, claimed asylum as a child in some countries. After an age assessment was requested, the Local Authority wrongly assessed her to be 23 when she was 15 years old and thus she was denied adequate protection which resulted in her being sexually abused. This theoretical case demonstrates the potential human cost of inadequate practice.

Therefore, it is very important for the procedures to proceed as soon as possible and to be result in a formal decision. (see Table 6).

Table 6: Unaccompanied and separated children in migration - age assessment procedures in $B \& H$

\begin{tabular}{|l|c|}
\hline Upon arrival/interception on the territory & No \\
\hline Within a week & No \\
\hline Within a month & Yes \\
\hline Does age assessment result in a formal decision & No \\
\hline
\end{tabular}

\section{Conclusion}

Trafficking should be treated in a more comprehensive fashion and thus expanded beyond sexual exploitation in order to encompass new forms namely criminal schemes of child begging and workers' exploitation, whereas the latter are deceived by false promises and deprived of all human rights and decent treatment.

Bosnia and Herzegovina should take additional steps to improve the identification of victims of human trafficking, in particular by following:

- Ensure that all possible and formally identified victims of trafficking, irrespective of their 
nationality and regardless of whether they cooperate with the investigating/prosecuting authorities and are accommodated in shelters, receive adequate assistance in accordance with their needs. This should include measures to:

- ensure adequate funding for $\mathrm{NGO}$ service providers to work with victims of THB;

- ensure access to health care to all victims of THB;

- develop capacities for assistance, including safe accommodation, adapted to the specific needs of male victims of THB;

- facilitate the reintegration of victims of trafficking into society by establishing longterm programmes and providing them with vocational training and assistance to find employment.

- make efforts to improve the identification of and assistance to child victims of trafficking, in particular by:

- ensuring that relevant actors take a proactive approach and increase their outreach work to identify child victims of $\mathrm{THB}$, including by continuing to pay attention to children in street situations; - providing further training to stakeholders (police, prosecutors, NGOs, centres for social welfare, child specialists) and guidance on the identification of child victims of THB, based on an agreed understanding of the concepts of trafficking for purpose of forced begging, forced criminality and early, child or forced marriages;

- providing support and services which are adapted to the needs of child victims of trafficking, including appropriate accommodation, access to education and vocational training;

- ensuring long-term monitoring of the reintegration of child victims of trafficking;

- ensuring that proper risk assessment is conducted before returning children to their parents, taking into account the best interests of the child;

- reviewing the criminal and civil procedures regarding compensation from perpetrators with a view to improving their effectiveness;

- ensuring that victims of THB are systematically informed of their right to claim compensation and the procedures to be followed;

- enabling victims of THB to exercise their right to compensation by guaranteeing them effective access to legal aid; - strengthening the capacity of law practitioners to help victims claim compensation and incorporating the issue of compensation in the training programmes for members of law enforcement agencies and the judiciary.

- there is no SOS phone for migrants.

- prosecutors do not apply same standards, and do not have same skills and experience in cases involving trafficking, which may cause certain level of victims discrimination due to inappropriate level of protection and support.

- police officers lack experience and training to recognise potential VOTS within the mixed migration flows, which occurs in many forms, including through labour exploitation primarily. Also, trafficking within the mixed migration flows cases have not been a familiar form of trafficking for judiciary

- very weak system for dealing with unaccompanied and separated children. Standard 


\section{Secuurity}

operating procedures for dealing with unaccompanied and separated children, Standard Operative procedures for the treatment of vulnerable categories of foreign persons when introduced and implemented could have new potential for identification/referral.

There has no statutory procedure, protocol, guidance or recommendations issued on age assessment procedures for unaccompanied and separated children in migration by different authorities

Domestic courts have no examined the application of age assessment for unaccompanied and separated children in migration procedures in individual cases. When it comes to the methods used to determine the age of unaccompanied children in migration in Bosnia and Herzegovina, we can see the prevailing "social oriented" methods: documents submitted or obtained during the process, estimation based on physical appearance, age assessment interview, social services assessment and psychological evaluation. On the other hand, other much more sophisticated methods are completely unknown to the Bosnia and Herzegovina but and other West Balkan Country.

Age assessment of unaccompanied and separated children in migration does not result in a formal decision.

- inadequate cooperation between public and private sector in prevention of trafficking and sexual exploitation of minors through travel and tourism industry as well as with associations of employers is new potential for development of indicators for identification/ referral.

- inadequate number of day centres for street children - Day centres for street children are recognised as an example of good practice and if accompanied with Psychosocial work on the street could be new potential for development of indicators for identification/referral.

\section{References}

1. Feltz, V., (2015), Age assessment for unaccompanied minors, MdM International Network Head Office, Nantes, France.

2. IOM - Flow Monitoring Surveys, (2017), The human trafficking and other exploitative practices indication survey migrants interviewed along the central and the Eastern Mediterranean routes compared, International organization for migration (IOM).

3. IOM - Trafficking in Persons Report (2017), State Department, Office To Monitor And Combat Trafficking In Persons.

4. IOM \& UNHCR (2017), Addressing the challenge of mixed migration: Protection and assistance in mixed migration, United States Department of State, Bureau of Population, Refugees and Migration.

5. Mujanović, E., Muratbegović, E., Budimlić, M., Obradović, V., (2016) Trgovina ljudima u Bosni i Hercegovini, Sarajevo; CPRC 
6. Muratbegović, E., Đuderija, S., Rizvo, S., Poturković, M., Arula, B., Jurošević, M., Hunček, S., (2015) Priručnik za multidisciplinarnu edukaciju edukatora stručnih djelatnika cenatara za socijalni rad u oblasti trgovanja ljudima

7. Rizvo, S., Đuderija, S., Majkić, F., Šeranić, M., Handanagić - Kavaz, A., i Mulić, Dž. (2006). Priručnik za službenike zaposlene u policiji (tužilaštvu), socijalnim i zdravstvenim institucijama - Zaštita djece od trgovine ljudima. Sarajevo: Ured državnog koordinatora za trgovinu ljudima i ilegalne migracije Ministarstvo sigurnosti BiH i Save the children Norway.

8. Rizvo, S. et al, (2015) Vodič za multidisciplinarnu saradnju u procesu rehabilitacije, resocijalizacije, reintegracije i repatrijacije žrtava trgovine ljudima u BiH, Ministarstvo sigurnosti BiH - Odsjek za borbu protiv trgovanja ljudima \& Asocijacija XY

9. Rizvo, S., et al. (2010) Smjernice o postupanju regionanih monitoringtimova za borbu protiv trgovine ljudima, Ministarstvo sigurnosti BiH - Odsjek za borbu protiv trgovanja ljudima \& Catholic Relief Services BiH

10. Strategy in the area of migrations and asylum and action plan for the period 2016-2020, Ministry of Security of Bosnia and Herzegovina, Sarajevo

11. Strategy to counter trafficking in human beings in Bosnia and Herzegovina 2013-2015, Ministry of Security of Bosnia and Herzegovina, Sarajevo.

12. Termiz, Dž. et al, (2010). Praktikum za socijalne radnike o pojavi i pojavnim oblicima: radne eksploatacije djece, trgovine ljudima u svrhu seksualnog iskorištavanja, prostitucije, pornografije i pedofilije. CRS i Ministarstvo sigurnosti BiH, Sarajevo. 